\title{
Diversity, Uses, and Threats in the Ghodaghodi Lake Complex, a Ramsar Site in Western Lowland Nepal
}

\author{
Pramod Lamsal, ${ }^{1}$ Krishna Prasad Pant, ${ }^{2}$ Lalit Kumar, ${ }^{3}$ and Kishor Atreya ${ }^{2}$ \\ ${ }^{1}$ Himalayan Geo-En. Pvt. Ltd., 133 Mokshya Marga, Kathmandu 4, Nepal \\ ${ }^{2}$ Kathmandu University, P.O. Box 6250, Dhulikhel, Nepal \\ ${ }^{3}$ University of New England, Armidale, NSW 2351, Australia
}

Correspondence should be addressed to Pramod Lamsal; pramod_lamsal@yahoo.com

Received 1 February 2014; Accepted 23 March 2014; Published 27 April 2014

Academic Editors: A. R. Atangana, I. Bisht, A. Chistoserdov, P. De los Ríos Escalante, and P. M. Vergara

Copyright (C) 2014 Pramod Lamsal et al. This is an open access article distributed under the Creative Commons Attribution License, which permits unrestricted use, distribution, and reproduction in any medium, provided the original work is properly cited.

\begin{abstract}
This study documents aquatic and terrestrial/riparian biodiversity in an anthropogenically disturbed Ramsar site, the Ghodaghodi Lake complex, in the Western Nepal surveyed during the summer season (March-April) of 2007. The study site comprises three major interconnected lakes: Ghodaghodi (138 ha), Nakharodi (70 ha), and Bainshwa (10 ha). Five transect lines for aquatic macrophytes and three transect lines and 37 sampling plots were laid to sample terrestrial/riparian plants, birds, and animals. Five sample plots were established for fish and aquatic bird. A total of 45 species of aquatic macrophytes, 54 species of terrestrial/riparian vegetation, 19 fish species, 41 bird species, 17 mammals (endangered and vulnerable), and 5 reptiles (critically endangered, vulnerable, and near threatened) were recorded at the lake complex. Local people have used most of the aquatic and terrestrial plants for different purposes while many of the potential medicinal plant species were still untapped. Persistent anthropogenic threats, like excessive harvesting and poaching, habitat destruction-population pressure, forest fragmentation, siltation, fertilizer and pesticide seepage, water pollution, overgrazing, and unmanaged irrigation system found over the lake complex, endangered the existing biodiversity. The suggested remedial measures are further exploration of medicinal potential, prioritization of in situ biodiversity conservation strategies, and implementation of awareness program at local level against anthropogenic threats.
\end{abstract}

\section{Introduction}

Wetlands are defined as lands transitional between terrestrial and aquatic eco-systems where the water table is usually at or near the surface or the land is covered by shallow water [1] and as in such state, supports considerable amount of biological diversity of the earth. The values of wetlands are receiving global attention due to their high contribution to human kind. But it is also a most delicate and threatened habitat as compared to other types because of the close interaction with us. Wetlands occupy approximately $5 \%(743,756 \mathrm{ha})$ of the total area of Nepal including high altitude glacial lakes, hot springs, ponds, oxbow lakes, river flood plains, swamps, and marshes and are critical habitats for many plant and animal species. MFSC [2] mentioned that the biogeographic location of Nepal and its complex mountain systems have given rise to a proportionately high level of biodiversity relative to its total area (i.e., 147,181 sq. km). Dugan [3] reported that wetlands occupy only about 4 to $6 \%$ of the Earth's surface but provide habitat for about $20 \%$ of the world's species. Although Nepal represents only $0.1 \%$ of the global terrestrial surface, it houses $0.3 \%$ of the world's species including $4.5 \%$ of the mammalian species, $4.2 \%$ of the butterfly species, $2.7 \%$ of the flowering plant species, $2.2 \%$ of the freshwater fish species, $1.6 \%$ of the reptile species, and $1 \%$ of the amphibian species [2]. A. R. Joshi and D. P. Joshi [4] reported that $25 \%$ of Nepal's estimated 7,000 vascular plant species are wholly or partially wetland dependent. Though wetlands form only $5 \%$ of Nepal's area, a total of 193 bird species (22\% of the total recorded in the country) fully depend on it [5]. Of the 35 globally threatened species recorded in Nepal, 15 (43\%) are wetland birds. In addition a total of $12(50 \%)$ out of 24 near-threatened species inhabit wetlands [6]. According to IUCN [7], there are 10 species of amphibians, 1 reptile species, and 8 species of flowering plants endemic to Nepal's wetlands. 
Medicinal plants have contributed significantly to the livelihood of Nepalese people [8] and their use is prevalent in different parts of the country $[9,10]$. In Nepal, traditional use of plant resources for medicinal purpose has a long history and is gaining popularity due to a lack of side effects, easy availability at affordable prices; and in many circumstances, it is the only source of health care to the poor communities [11]. Around 6,500 plant species are used for medicinal purposes in Asia [12] while at least 1,600 to 1,900 plant species are used traditionally for medicinal practices in Nepal $[13,14]$. The government has also recognized the importance of proper conservation of medicinal plant diversity and the issue is highlighted in the national level Nepal Biodiversity Strategy [2]. It is estimated that only $15-20 \%$ of the population of Nepal, who live in and around urban areas, have access to modern medicinal facilities, whereas the rest depend on traditional medicines [8].

Biodiversity loss has become a major issue over the last few decades and its protection has emerged as a main agenda within national nature conservation policies, international conventions, conservation targets, and political programmes [15]. Freshwater biodiversity has been threatened by a number of major impacts such as overexploitation, water pollution, and flow modification including water abstraction, destruction, or degradation of habitat as well as invasion by alien species [16]. The diversity and distribution of wetland flora and fauna are affected by the changes in the water chemistry [17]. Schuyt [18] reported various threats to the major wetlands of Africa: reclamation for agriculture and settlement expansion at Nakivubo wetland, Uganda; reduction of water level by overabstraction within catchment and degradation of the catchment itself due to overpopulation, overexploitation of wetland resource, soil erosion and siltation, pollution from the use of agrochemicals, and invasion by water hyacinth at Lake Chilwa wetland, Malawi; reduced water flow by overabstraction, aquatic weed infestation, overuse of wetland resource, pollution, and deforestation at Zambezi Basin wetland, South Africa. Five threats have been documented by Dudgeon et al. [19] including overexploitation of the natural resources, water pollution from the siltation and agricultural wastes, flow modification, habitat degradation, and exotic species invasion, whose combined and interactive influences are the causes of declining populations and shrinking global freshwater biodiversity and could be compared with the existing condition of Ghodaghodi Lake complex. Siwakoti and Karki [20] highlighted the heavy dependency of the poor people on wetlands as a major issue for wetland conservation in Nepal. The authors were of the view that the involvement of wetland-dependent communities in the decision-making process could assist sustainable resource conservation efforts and help them benefit in lieu of conservation. The effective systems of resource management can ensure that biological resources not only survive, but increase as well while they are being used by the people, thus providing the foundation for sustainable development [21]. Protection of freshwater biodiversity is perhaps the ultimate conservation challenge in the current global scenario [19]. Since wetlands are considered as a common property resource, the conservation of this ecosystem is an uphill task unless the principal stakeholders are involved in the process.

Ghodaghodi Lake complex is the largest interconnected natural lake system in the plain land of Nepal and was designated a Ramsar site in 2003 due to its high biodiversity value. Though it is a very important lake ecosystem, only a few studies $[7,22]$ are found on the biodiversity and threats, while medicinal uses of plant species are hardly tapped by the scientific research. IUCN [7] carried out a full inventory of the Lake Complex spread over six months (Nov.May, 1997/98) while Kafle [22] studied certain lake diversity focussing only on Ghodaghodi Lake in summer (Jan.-Feb.) and winter (Sept.-Oct.) of 2005. This study investigates the terrestrial/riparian and aquatic biodiversity of the lake complex, existing and potential utility including the medicinal values of the plant species, while at the same time identifies the anthropogenic threats to the lake biodiversity. The results of this research are intended to inform managers and decision makers about the importance of this lake ecosystem and how planning decisions could impact the lake's biodiversity.

\section{Materials and Methods}

2.1. Study Area. The Ghodaghodi Lake complex $\left(28^{\circ} 41^{\prime} 17^{\prime \prime}\right.$ $\mathrm{N}, 80^{\circ} 56^{\prime} 47^{\prime \prime}$ E) lies in the Kailali district of far Western Terai in Nepal (Figure 1) and is $205 \mathrm{~m}$ above mean sea level. This wetland covers approximately 2500 ha, 14 large and small oxbow lakes with associated marshes, swamps, streams, springs, seasonal marshy grasslands, and artificial wetlands (canals, irrigated fields, ponds, etc.) surrounded by tropical deciduous mixed Shorea robusta forest in the lower slopes of Siwalik hills. Major lakes of the complex include Ghodaghodi (138 ha), Nakharodi (70 ha), and Baishawa (10 ha) [20].

The lake system is connected with extensive forests along the Siwalik (Churia) Hills to the north and falls between two of Terai's protected areas-the Royal Bardia National Park and the Royal Suklaphanta Wildlife Reserve-and functions as an important corridor for the movement of wildlife. The lake complex is characterised by three types of wetland habitats: (i) riverine including perennial rivers and river flood plain; (ii) lacustrine including oxbow lakes and ponds; and (iii) palustrine including marshes and swamps. Marshy areas on the fringes of the lakes are subject to periodic inundation. Only Ghodaghodi and Nakharodi Lakes are perennial while Bainshwa is seasonal and turns marshy during the dry season. Similarly, the wetland forest complex has three types of forest habitats: Shorea robusta forest, Terminalia alata forest, and mixed deciduous riverine forest.

The area has a tropical monsoon climate. The average annual rainfall ranges between $1630 \mathrm{~mm}$ (recorded at Tikapur, $35 \mathrm{~km}$ to the southeast of the lake) and $1705 \mathrm{~mm}$ (recorded at Dhangadhi) where about $80-85 \%$ of total rainfall occurs during the monsoon period (mid-June to late September). The average monthly maximum temperature ranges from $21^{\circ} \mathrm{C}$ to $38^{\circ} \mathrm{C}$ and minimum $6^{\circ} \mathrm{C}$ to $25^{\circ} \mathrm{C}$ (at Tikapur). At Dhangadhi, the maximum temperature ranges from $22^{\circ} \mathrm{C}$ to $37^{\circ} \mathrm{C}$ and minimum from $5^{\circ} \mathrm{C}$ to $25^{\circ} \mathrm{C}$. The soil at the bed and surrounding area of the lake complex was 


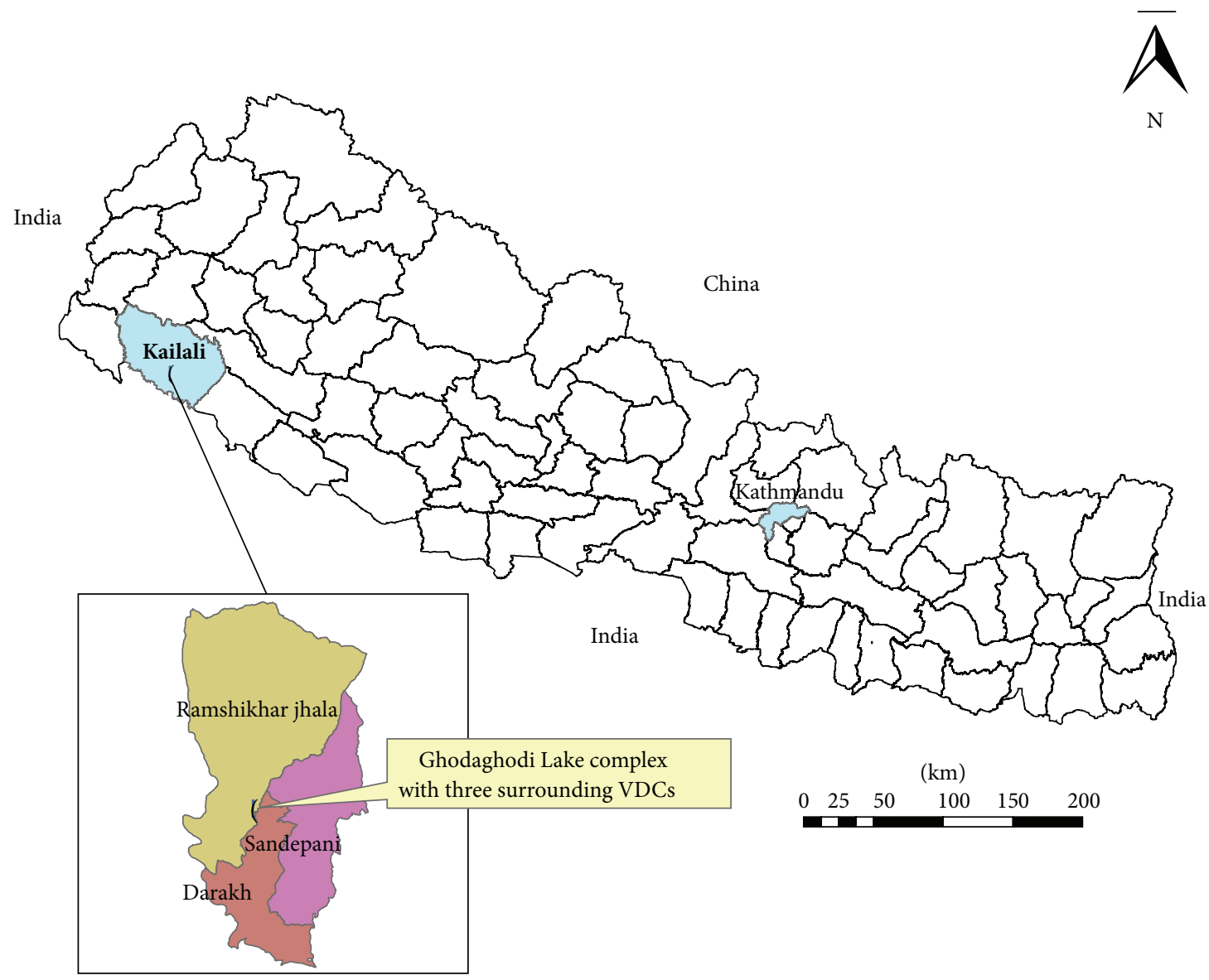

FIgURE 1: Map showing Ghodaghodi Lake complex and adjoining villages.

almost of the same type with very little horizontal spatial variation. The predominant soil type was high in plasticity, of low permeability clay of yellowish to light brown colour. Low permeability of the soil was on the basis that loss of water through seepage and deep percolation seemed to be considerably low. No rock outcrop could be seen in the vicinity of the lake area. The lake is fed by direct precipitation during the monsoon season and by surface flows from the watershed area, ground water springs, and small streams. Water depth varies from 1-2 $\mathrm{m}$ during the dry period to 3-4 m during the monsoon season [23].

The wetland complex is bordered by three local politicoadministrative units called Village Development Committees (VDC): Sandepani in the East, Darakh in the South, and Ramshikharjhala in the North and West. Around $60 \%$ of the total area is used as agricultural land, 37\% land is under forest covers, lakes, common pastures, and scrubs; $2 \%$ percent under settlements and roads while rivers and streams cover $1 \%$ percent of the total land. Farming with traditional use of natural resources is the major occupation of the people living in the lake area. The present uses of lake resources include fishing, livestock grazing and collection of fodder, firewood, and nontimber forest products including medicinal plants. Tharus, an indigenous ethnic group of the lake area, comprising more than $50 \%$ of the total population, are the most dependent community on wetland resources [20]. The uses of lake resources by local people, mainly fodder, aquatic macrophytes, livestock grazing, and fishing, were also mentioned by [24]. The total households and population of these VDCs have been increased sharply (73\% and 38\%, resp.) in the last decade as shown in the Table 1.

2.2. Data Collection. Data were collected during March-April 2007. Therefore the species documented in this study can only be validated in the summer months of Nepal. Data on both terrestrial/riparian and aquatic plants were recorded in the floral category. For aquatic plants, submerged, free-floating, floating leaves, and emergent plants were collected. Sampling was undertaken in such a way that it would cover all the representative habitats of aquatic flora. Shorelines as well as open water areas, floating as well as submerged vegetations were sampled across the lake in transect lines in a boat. Five transect lines, three at Ghodaghodi $(719 \mathrm{~m}, 1673 \mathrm{~m}$, and $1572 \mathrm{~m})$, one at Bainshwa $(460 \mathrm{~m})$, and one at Nakharodi (960 m), were established; and quadrat method of random sampling as mentioned by Ludwig and Reynolds [27] was followed to collect macrophytes. Local people and secondary literature [28-31] were consulted for field identification of aquatic macrophytes. 
TABLE 1: Household and population increment in the lake adjoining villages.

\begin{tabular}{lcccc}
\hline \multirow{2}{*}{ VDC } & \multicolumn{2}{c}{ Total household } & \multicolumn{2}{c}{ Total population } \\
& 2001 & 2011 & 2001 & 2011 \\
\hline Darakh & 1,694 & 3,153 & 12,171 & 17,623 \\
Ramsikharjhala & 1,824 & 3156 & 13,560 & 18,016 \\
Sandepani & 2,592 & 4,278 & 17,956 & 24,892 \\
\hline Total & 6,110 & 10,587 & 43,687 & 60,531 \\
\hline
\end{tabular}

Source: CBS $[25,26]$.

For terrestrial plants, trees, shrubs and herbs were surveyed. Three transect lines, each from eastern, western, and northern parts, passing through the surrounding forest of Ghodaghodi Lake complex, were demarcated. A total of 37 quadrat plots, also used by Dongol [32], of $10 \mathrm{~m} \times 10 \mathrm{~m}$ were laid on the ground at intervals of $250 \mathrm{~m}$ along those transect lines in an alternate side. Similarly, nested plots of $3 \mathrm{~m} \times 3 \mathrm{~m}$ and $1 \mathrm{~m} \times 1 \mathrm{~m}$ on the lower right-hand side corner were laid within the $10 \mathrm{~m} \times 10 \mathrm{~m}$ plot for shrub and herb inventory, respectively.

Field identification of the plant species was carried out using standard literature [30,33-35] and with the help of local people. Herbaria were prepared for unidentified plant samples and brought to the Kathmandu University Laboratory for expert identification. Unidentified species were also taken to the Government accredited National Herbarium Centre at Godavari, Lalitpur.

In the faunal category, the survey was undertaken for fishes, birds, mammals, and reptiles. For fish, five sampling areas were purposively identified, three in Ghodaghodi Lake and two in Bainshwa and Nakharodi. Fishing nets were kept overnight and the fish catch was collected next morning and repeated for three consecutive days. We followed Shrestha [36] for fish specimen identification. Local fish markets located at Sukhad Bazar were surveyed twice in three-day intervals to identify additional species harvested from the lake.

For terrestrial birds, the same plots of terrestrial vegetation assessment were considered. Bird surveys were carried out before vegetation surveys in the morning from $0500 \mathrm{hr}$ to $0700 \mathrm{hr}$ through direct observation via binoculars $(8 \times 30)$ and a call count method. Birds were surveyed for a total of five consecutive days. For aquatic birds, the same sampling points used for fish were considered. The survey procedure and period were similar to those of terrestrial birds and in both cases, we followed the literature of BCN and DNPWC [37] for field identification. The same stations were used for the survey of aquatic animals.

For terrestrial wildlife, the transect lines setup for terrestrial plant assessments was used. Each transect was walked three times and wildlife species were observed. This survey was carried out before vegetation surveys so that habitats could remain undisturbed and animals could be spotted. Indirect methods such as faecal, hair, and horns were also used to determine the presence of wildlife species.

Anthropogenic threats as well as additional information on exiting biodiversity and local medicinal uses of plant species were observed and recorded through field observations, focus group discussions (FGDs), and key informant interviews (KII). A total of three focus group discussions, one at each VDC and six key informant interviews, two at each VDC, were conducted. Field observations were made using a recording sheet and camera while a checklist containing all aspects of biodiversity, medicinal uses, and existing threats was developed, pretested, and used for the FGD. A total of 8-10 people including ethnic traditional healers were made available for FGD in order to gather information, crosscheck, and validate. Older members of the community and local schoolteachers were selected for key informant interviews.

\section{Results and Discussion}

\subsection{Plant Diversity}

3.1.1. Aquatic Plant Diversity. A total of 45 species of aquatic plants including 9 submerged, 6 free-floating, 21 floating leaved, and 9 emergent species (Table 2) were found in the Ghodaghodi, Bainshwa, and Nakharodi Lakes. Lotus (Nelumbo nucifera), water chestnut (Trapa bispinosa), water lilies (Nymphaea nouchali), and pondweed (Potamogeton natans) were the major anchored leaf-floating species. Hydrilla (Hydrilla verticillata), hornwort (Ceratophyllum demersum), and pondweeds (Potamogeton spp.) were the major submerged species. Similarly, feathered mosquito fern (Azolla imbricate), duck weed (Lemna minor), and Asian watermeal (Wolffia globosa) were found to be the dominant free-floating species. An inventory of the Ghodaghodi Lake by IUCN [7] resulted in 107 species of aquatic macrophytes, whereas a seasonal study by Kafle [22] reported only 22 aquatic plant species. A total of seven categories of existing uses were found from the lake aquatic macrophytes. Out of the 45 plant species identified in the wetland complex, 22 species have been used for different purposes, such as human medicines (11 species), fodder (7 species), food (6 species), green manure ( 8 species), food for fish (5 species), food for duck (5 species), and industrial (2 species). There were still 23 macrophytes species untapped for any uses including medicines, though used in other parts of the country as well as South Asia.

3.1.2. Terrestrial/Riparian Plant Diversity. A total of 54 terrestrial/riparian plant species (Table 3) were found, out of which 25 were trees, 7 shrubs, and 22 herbs. Shorea robusta and Terminalia alata were the major terrestrial tree species. Other species include Syzygium cumini, Aegle marmelos, Acacia catechu, and Dalbergia latifolia. The forest also contained lianas and undergrowth, and the secondary layer was formed by a variety of trees including Mallotus philippensis. A rare spiny shrub Gardenia campanulata, with highly restricted distribution within Nepal, was also found. Syzygium cumini and Syzygium jumbos were the dominant species of swamp forest, particularly around Nakharodi Lake. However, a total of 137 and 35 terrestrial/riparian plant species were identified by IUCN [7] and Kafle [22], respectively, at Ghodaghodi Lake. Local people in Ghodaghodi Lake complex traditionally use 
TABLE 2: Aquatic macrophytes recorded in the Ghodaghodi Lake complex.

\begin{tabular}{|c|c|c|}
\hline Species & Potential uses & $\begin{array}{l}\text { Existing uses by local people in the } \\
\text { Ghodaghodi Lake area }\end{array}$ \\
\hline \multicolumn{3}{|l|}{ Submerged } \\
\hline Ceratophyllum demersum & $\begin{array}{l}\text { Human medicine }[38,39] \text {; fish food }[40,41] \text {; } \\
\text { green manure }[41]\end{array}$ & Fish food; duck food; green manure \\
\hline Hydrilla verticillata & Fish food [42] & $\begin{array}{l}\text { Fish food; duck food; fodder; green } \\
\text { manure }\end{array}$ \\
\hline Limnophila sessiliflora & N/A & NONE \\
\hline Potamogeton natans & N/A & NONE \\
\hline Potamogeton crispus & N/A & NONE \\
\hline Potamogeton pectinatus & $\mathrm{N} / \mathrm{A}$ & NONE \\
\hline Utricularia flexuosa & $\mathrm{N} / \mathrm{A}$ & Human medicine; green manure \\
\hline Utricularia stellaris & N/A & NONE \\
\hline Vallisneria spiralis & Fish food [42] & NONE \\
\hline \multicolumn{3}{|l|}{ Free-floating } \\
\hline Azolla imbricata & $\begin{array}{l}\text { Green manure }[39,43] \text {; fodder [39]; duck } \\
\text { food [39] }\end{array}$ & Fish food; duck food; green manure \\
\hline Hygroryza aristata & Fodder [41] & Food; fodder \\
\hline Lemna minor & N/A & Fish food; duck food; green manure \\
\hline Pistia stratiotes & $\begin{array}{l}\text { Human medicine }[38] \text {; duck food }[41,43] \text {; } \\
\text { green manure }[38,43]\end{array}$ & Human medicine; green manure \\
\hline Ricciocarpus natans & N/A & NONE \\
\hline Wolffia globosa & N/A & NONE \\
\hline \multicolumn{3}{|c|}{ Submerged rooted with floating leaves } \\
\hline Caldesia parnassifolia & N/A & NONE \\
\hline Jussiaea repens & N/A & NONE \\
\hline Nymphaea nouchali & Food $[41]$ & NONE \\
\hline Nelumbo nucifera & Human medicine [38]; food [41-43] & Human medicine; food; fodder \\
\hline Nymphoides cristatum & N/A & NONE \\
\hline Ottelia alismoides & Food [39] & NONE \\
\hline Potamogeton nodosus & Duck food [42] & NONE \\
\hline Trapa bispinosa & Human medicine [44] & Human medicine; food \\
\hline \multicolumn{3}{|l|}{ Emergent } \\
\hline Alisma plantago-aquatica & N/A & NONE \\
\hline Cassia sophera & Human medicine [45] & NONE \\
\hline Centella asiatica & $\begin{array}{l}\text { Human medicine [40, 46-49]; veterinary } \\
\text { medicine [32] }\end{array}$ & Human medicine; food \\
\hline Cyperus diffuses & Fodder $[42]$ & NONE \\
\hline Cyperus rotundus & Human medicine $[14,49]$ & Human medicine; fodder \\
\hline Eclipta prostrata & Human medicine $[14,42,49]$; food [38] & Human medicine; fodder \\
\hline Equisetum debile & Human medicine [39] & Human medicine; green manure \\
\hline Fimbristylis dichotoma & Fodder [43] & NONE \\
\hline Hygrophila auriculata & Human medicine $[43,50]$; food $[41]$ & Human medicine \\
\hline Ipomea fistulosa & $\mathrm{N} / \mathrm{A}$ & NONE \\
\hline Ipomea aquatica & Human medicine $[43,51]$; food $[38,41,42]$ & $\begin{array}{l}\text { Human medicine; fish food; duck food; } \\
\text { food }\end{array}$ \\
\hline Limnophila indica & Human medicine [39] & NONE \\
\hline Ludwigia octovalvis & Human medicine $[38,39]$ & NONE \\
\hline Monochoria vaginalis & Human medicine $[39,43]$ & Food \\
\hline Phragmites karka & $\begin{array}{l}\text { Human medicine [38]; fodder [39]; } \\
\text { industrial [41] }\end{array}$ & Fodder; industrial use \\
\hline
\end{tabular}


TABLE 2: Continued.

\begin{tabular}{lcc}
\hline Species & Potential uses & $\begin{array}{c}\text { Existing uses by local people in the } \\
\text { Ghodaghodi Lake area }\end{array}$ \\
\hline $\begin{array}{l}\text { Polygonum barbatum } \\
\text { Ranunculus sceleratus } \\
\text { Rumex dentatus }\end{array}$ & Food [41] & NONE \\
Human medicine [43, 52] & Human medicine \\
Saccharum spontaneum & Human medicine [53]; food [43]; green \\
Sonchus asper & Human medicine [54]; fodder [41, 43]; \\
Typha angustifolia & industrial [39, 41] & Food; green manure \\
\hline
\end{tabular}

Note. Human and veterinary medicine includes the uses of a plant in different ailments by local people in the study area as well as in other parts of South Asia. Food includes vegetables, pickle, and spices consumed by human. Industrial includes use of a plant for handicraft, oils and tannin, and others that can provide direct cash benefit. N/A: information could not be found in the scientific literature by authors. NONE: no use of a plant in the study area so far.

several terrestrial/riparian plant species to sustain their livelihood. A total of eight categories of existing uses were found from the lake terrestrial plant resources. Out of the 54 plant species identified in the wetland complex, 35 species have been used for different purposes, such as human medicines (29 species), veterinary medicine (5 species), fodder (13 species), fruit (8 species), timber (7 species), firewood (6 species), industrial (4 species), and food (3 species). A total of 19 species were still untapped in the study area though they have been found to be used for different purposes including medicine in other parts of the country as well as South Asia.

\subsection{Animal Diversity}

3.2.1. Fish Diversity. A total of 19 fish species were found in the Ghodaghodi Lake complex (Table 4). IUCN [7] identified 27 species of fish from the same area.

3.2.2. Avifaunal Diversity. Wetland birds comprise a significant portion of the avian fauna recorded in Nepal [71]. This study found a total of 41 species of birds representing 20 families in the Ghodaghodi Lake complex (Table 5). IUCN [7] documented 140 species of avifauna whereas Kafle [22] reported 60 species. The lower number of bird species in our study compared to others may be because of seasonal effects; that is, IUCN inventory was for six months and Kafle has documented avifauna seen in two seasons.

3.2.3. Mammalian Diversity. A total of 17 species of mammals belonging to 12 families were recorded in the Ghodaghodi Lake complex (Table 6). These included endangered species like fishing cat (Felis viverrina) and Asian elephant (Elephas maximus), while the common otter (Lutra lutra), leopard cat (Felis bengalensis), leopard (Panthera pardus), blue bull (Boselaphus tragocamelus), and spotted deer (Axix axix) fall under the vulnerable category. IUCN [7] reported 34 mammalian species from the same complex. Some of the mammals such as jungle hare, spotted deer, and wild boar are used by the local people for bush meat.
3.2.4. Reptile Diversity. This study found a total of 6 species of reptiles representing 5 families in the Ghodaghodi Lake complex (Table 7). It also showed the existence of the vulnerable marsh mugger (Crocodylus palustris) in different parts of the Ghodaghodi Lake. It was informed by the local people that marsh mugger often travels near Bainshwa Lake by crossing a small ridge that separates these two lakes. Similarly, the critical endangered red crowned roofed turtle (Kachuga kachuga) and near-threatened Indian python (Python molurus) were also found to exist in the lake. Ghodaghodi Lake supports the habitat for additional species of turtles including flap-shell turtle (Lissemys punctata) and Indian roofed turtle (Kachuga tecta).

\subsection{Potential Anthropogenic Threats to Ghodaghodi Lake} Complex Biodiversity. Freshwater ecosystems are affected by overharvesting of the resources and habitat destruction. The major drivers of the destruction are human demography, excessive resource use, increased water consumption, technological development, and social organization [74]. These changes are responsible for some major alteration like physical restructuring of aquatic ecosystems, introduction of exotic species, discharge of toxic substances, and overharvesting of resources [75]. Bhandari [76] observed conversion of wetland because of overexploitation of resources, pollution of water, invasion of alien species, encroachment to the lake area, and sedimentation as the major categories of threats in Nepal. The Ghodaghodi Lake complex supports several aquatic and terrestrial flora and fauna, contributing to wetland biodiversity conservation in the area. However, as other wetlands, Ghodaghodi Lake complex is no exception, receiving threat from unsustainable harvesting and illegal poaching, expanding population, changes in land use, and overexploitation of lake resources. Most of these threats we observed are anthropogenic in nature and can be broadly categorized into (i) unsustainable harvesting and poaching and (ii) habitat destruction.

3.3.1. Unsustainable Harvesting and Poaching. Local people heavily harvested aquatic and terrestrial plants and fishes. Illegal tree felling and smuggling of Shorea robusta timber 
TABLE 3: Terrestrial/riparian plants recorded within the forest adjacent to the Ghodaghodi Lake complex.

\begin{tabular}{|c|c|c|}
\hline Species & Potential uses & $\begin{array}{l}\text { Existing uses by local people in the } \\
\text { Ghodaghodi Lake area }\end{array}$ \\
\hline \multicolumn{3}{|l|}{ Herb } \\
\hline Aerva lanata & Human medicine [50]; food [32] & NONE \\
\hline Achyranthes aspera & Human medicine $[40,49,56,57]$ & Human medicine; veterinary medicine \\
\hline Ageratum conyzoides & Human medicine [57-59] & Human medicine \\
\hline Alternanthera sessilis & Human medicine $[60]$ & NONE \\
\hline Asteracantha longifolia & $\mathrm{N} / \mathrm{A}$ & Human medicine; fodder \\
\hline Bacopa monnieri & Food $[41,43]$ & NONE \\
\hline Barleria cristata & N/A & NONE \\
\hline Blumea mollis & Human medicine [61] & Human medicine; fodder \\
\hline Colocasia antiquorum var. esculenta & N/A & NONE \\
\hline Chenopodium ambrosioides & Human medicine [55] & NONE \\
\hline Cirsium wallichii & N/A & NONE \\
\hline Dopatrium junceum & N/A & $\begin{array}{l}\text { Human medicine; veterinary medicine; } \\
\text { food; fodder }\end{array}$ \\
\hline Dichanthium annulatum & N/A & NONE \\
\hline Echinochloa colonum & N/A & Human medicine \\
\hline Oxalis corniculata & $\begin{array}{l}\text { Human medicine }[32,48] \text {; veterinary medicine } \\
{[32] \text {; food [32]; fodder [32] }}\end{array}$ & $\begin{array}{l}\text { Human medicine; veterinary medicine; } \\
\text { food; fodder }\end{array}$ \\
\hline Polypogon monspeliensis & N/A & NONE \\
\hline Phyla nodiflora & Human medicine [32] & Human medicine \\
\hline Scirpus grossus & Industrial [41] & NONE \\
\hline Scirpus articulates & N/A & Human medicine \\
\hline Scoparia dulcis & Human medicine $[32,62]$ & Human medicine \\
\hline Solanum nigrum & Human medicine $[51,63]$ & NONE \\
\hline Vernonia cinerea & Human medicine [61] & Human medicine \\
\hline \multicolumn{3}{|l|}{ Shrub } \\
\hline Calotropis gigantea & Human medicine $[48,49,54,64]$ & Human medicine \\
\hline Colebrookea oppositifolia & N/A & Human medicine; veterinary medicine \\
\hline Gardenia campanulata & N/A & NONE \\
\hline Murraya koenigii & Human medicine $[14,49]$ & Fruit; food; fodder; firewood \\
\hline Phoenix acaulis & N/A & NONE \\
\hline Woodfordia fruticosa & $\begin{array}{l}\text { Human medicine }[48,54] \text {; veterinary medicine } \\
{[32] ; \text { industrial }[32,65]}\end{array}$ & $\begin{array}{l}\text { Human medicine; veterinary medicine; } \\
\text { industrial use }\end{array}$ \\
\hline Zizyphus mauritiana & Human medicine $[48,49]$ & Human medicine; fruit; industrial use \\
\hline \multicolumn{3}{|l|}{ Tree } \\
\hline Acacia catechu & $\begin{array}{l}\text { Human medicine }[48,54] \text {; timber [32]; firewood } \\
{[32] \text {; industrial [32] }}\end{array}$ & Human medicine; industrial \\
\hline Aegle marmelos & Human medicine [49]; food [54]; fruit [54] & Human medicine; fruit \\
\hline Artocarpus lakoocha & Human medicine $[54,62]$ & Human medicine \\
\hline Bauhinia purpurea & $\begin{array}{l}\text { Human medicine [53]; food [64]; fodder [64]; } \\
\text { industrial [32] }\end{array}$ & $\begin{array}{l}\text { Human medicine; fodder; food; firewood; } \\
\text { industrial use }\end{array}$ \\
\hline Careya arborea & Human medicine [66] & NONE \\
\hline Cassia fistula & Human medicine $[48,53]$ & Human medicine; firewood \\
\hline Dalbergia sissoo & $\begin{array}{l}\text { Human medicine [48]; fodder [64]; timber [32]; } \\
\text { firewood [32] }\end{array}$ & Human medicine; timber; fodder \\
\hline Dalbergia latifolia & N/A & Timber \\
\hline Dillenia pentagyna & Food [32] & NONE \\
\hline Ficus racemosa & Fodder [54]; fruit [54] & Fodder \\
\hline
\end{tabular}


TABLe 3: Continued.

\begin{tabular}{|c|c|}
\hline Species & Potential uses \\
\hline Lannea coromandelica & Human medicine \\
\hline Mangifera indica & Human medicine [5 \\
\hline Mallotus philippensis & Human medicine $[48,49,64]$ \\
\hline Ougeinia dalbergioides & N/A \\
\hline Psidium guajava & Human medicine [ 4 \\
\hline Schleichera oleosa & $\begin{array}{r}\text { Human medicine }[32,68] \text {; foo } \\
\text { industrial [32] }\end{array}$ \\
\hline Shorea robusta & Fodder [32]; industrial [32]; fi \\
\hline Spondias pinnata & Human medicine $[54,68$ \\
\hline Syzygium cumini & $\begin{array}{r}\text { Food }[50,54,64] ; \text { firewood [32 } \\
\text { fodder [32] }\end{array}$ \\
\hline Syzygium jambos & N/A \\
\hline Terminalia bellerica & $\begin{array}{r}\text { Human medicine }[48,54] \text {; timb } \\
{[32] \text {; industrial }[20}\end{array}$ \\
\hline Terminalia alata & Fodder $[32,54]$; timber $[32,61$ \\
\hline Toona ciliata & Human medicine \\
\hline Trewia nudiflora & $\begin{array}{l}\text { Human medicine [69]; food } \\
{[32,64] \text {; fodder }[32,64]}\end{array}$ \\
\hline Zizyphus rugosa & Human medicine \\
\hline \multicolumn{2}{|l|}{ Climber and vine } \\
\hline Bauhinia vahlii & Fodder [54]; fruit [54]; inc \\
\hline Spatholobus parviflorus & N/A \\
\hline \multicolumn{2}{|c|}{$\begin{array}{l}\text { Note. Human and veterinary medicine includes the uses of a plant in differen } \\
\text { Food includes vegetables, pickle, and spices consumed by human. Industrial } \\
\text { direct cash benefit. N/A: information could not be found in the scientific lite }\end{array}$} \\
\hline \multicolumn{2}{|c|}{ TABLE 4: Fishes recorded in the Ghodaghodi Lake complex. } \\
\hline Scientific name & Family \\
\hline Colisa fasciatus & Belonidae \\
\hline Clarias batrachus & Claridae \\
\hline Channa striatus & Channidae \\
\hline Channa punctatus & Channidae \\
\hline Lepidocephalus guntea & Cobitidae \\
\hline Channa gachua & Channidae \\
\hline Puntius gelius & Cyprinidae \\
\hline Puntius conchonius & Cyprinidae \\
\hline Puntius chola & Cyprinidae \\
\hline Puntius sophore & Cyprinidae \\
\hline Rasbora daniconius & Cyprinidae \\
\hline Heteropneustes sp. & Saccobranchidae \\
\hline Labeo boga & Cyprinidae \\
\hline Mastacembelus pancalus & Mastacembelidae \\
\hline Xenentodon cancila & Belonidae \\
\hline Mastacembelus armatus & Mastacembelidae \\
\hline Mystus vittatus & Bagridae \\
\hline Notopterus notopterus & Notopteridae \\
\hline
\end{tabular}

and Acacia catechu were common practices found during the study period. Human encroachments were severe in

the southeastern parts of Nakharodi Lake; and eastern, southeastern, and northwestern parts of Ghodaghodi Lake. Siwakoti and Karki [20] mentioned illegal cutting and encroachment at the lake area. Mammals and birds suffer from poaching by local people as well as illegal hunters from other areas of the country. It has been reported that local poachers have always been active for killing wild animals in the lake area. Illegal hunting of wild boars, deer, and other wildlife as well as bird trapping and egg collection were prevalent in the area, either by the villagers or professional poachers. Neupane et al. [77] reported similar threats of poaching and illegal hunting of small mammals, fish, and birds at wetlands located in the far Western Nepal.

3.3.2. Habitat Destruction. Habitat destruction affects both harvested species such as aquatic plants and fishes and even nonharvested species of weeds, reptiles, and microorganisms. Large mammals like tiger, sloth bear, and most of the deer species were not sighted in the area for a couple of years. The current population pressure in the area and fragmentation of the forest and increased agricultural land have been identified as factors contributing to this degradation. The local people attributed this to the shrinkage and thinning of forest areas for the establishment of settlements around the lake that have heavily degraded the habitat of these mammals. The other drivers of habitat destruction in the 
TABLE 5: Avifauna recorded in the Ghodaghodi Lake complex.

\begin{tabular}{|c|c|}
\hline Scientific name & Family \\
\hline Egretta alba modesta & Ardeidae \\
\hline Metopidius indicus & Jacanidae \\
\hline Nettapus coromandelianus & Anatidae \\
\hline Gallinula chloropus & Rallidae \\
\hline Fulica atra & Rallidae \\
\hline Ardea intermedia intermedia & Ardeidae \\
\hline Anhinga melanogaster & Anhingidae \\
\hline Phalacrocorax niger & Phalacrocoracidae \\
\hline Spilornis cheela cheela & Accipitridae \\
\hline Ardeola grayii & Ardeidae \\
\hline Accipiter nisus & Accipitridae \\
\hline Dendrocygna javanica & Anatidae \\
\hline Buceros bicornis & Bucerotidae \\
\hline Anastomus oscitans & Ciconiidae \\
\hline Porphyrio porphyrio & Rallidae \\
\hline Ardea cinerea & Ardeidae \\
\hline Amaurornis phoenicurus & Rallidae \\
\hline Oriolus xanthornus & Oriolidae \\
\hline Threskiornis melanocephalus & Threskiornithidae \\
\hline Ardea purpurea & Ardeidae \\
\hline Dinopium shorii & Picidae \\
\hline Megalaima asiatica & Capitonidae \\
\hline Megalaima haemacephala & Capitonidae \\
\hline Coracias benghalensis & Muscicapidae \\
\hline Merops philippinus & Meropidae \\
\hline Merops orientalis & Meropidae \\
\hline Halcyon smyrnensis & Alcedinidae \\
\hline Cuculus varius & Cuculidae \\
\hline Centropus sinensis & Cuculidae \\
\hline Psittacula eupatria & Psittacidae \\
\hline Pernis ptilorhyncus & Accipitridae \\
\hline Long-tailed shrike* & Campephagidae \\
\hline Rufous hooded oriale* $^{*}$ & Oriolidae \\
\hline Pericrocotus flammeus & Campephagidae \\
\hline Dicrurus paradiseus & Corvidae \\
\hline Copsychus malabaricus & Muscicapidae \\
\hline Cinnyris asiaticus & Nectariniidae \\
\hline Psittacula krameri & Psittacidae \\
\hline Anastomus oscitans & Ciconiidae \\
\hline Pandion haliaetus haliaetus & Accipitridae \\
\hline Dendrocitta vagabunda & Corvidae \\
\hline
\end{tabular}

${ }^{*}$ Common name.

lake complex include rites and rituals, unmanaged irrigation systems for agricultural fields, runoff from agricultural fields and siltation, and overgrazing.

The wastes generated from the rites and rituals performed by the religious pilgrims, especially indigenous Tharu community, on the shore of the lake, have contributed significantly to water pollution in the Ghodaghodi Lake complex. They celebrate by sacrificing domestic pigs, goats, chickens,
TABLE 6: Mammals recorded in the Ghodaghodi Lake complex.

\begin{tabular}{|c|c|c|}
\hline Scientific name & Family & Common name \\
\hline Macaca mulatta (LC, II) & Cercopithecidae* & Rhesus monkey \\
\hline Presbytis entellus (I) & Cercopithecidae* & Hanuman langur \\
\hline Felis chaus (LC) & Felidae ${ }^{* *}$ & Jungle cat \\
\hline Felis viverrina $(\mathrm{EN}, \mathrm{II})$ & Felidae ${ }^{* *}$ & Fishing cat \\
\hline Felis bengalensis (VU, II) & Felidae ${ }^{* *}$ & Leopard cat \\
\hline Panthera pardus (VU, I)) & Felidae** & Leopard \\
\hline Canis aureus (LC) & Canidae* $^{*}$ & Jackal \\
\hline Lutra lutra (NT, I) & Mustelidae* $^{*}$ & Otter \\
\hline Pteropus sp. (LC) & Pteropodidae* & Bat \\
\hline Funambulus sp. & Sciuridae* & Squirrel \\
\hline Petaurista petaurista (LC) & Sciuridae $^{*}$ & Flying squirrel \\
\hline Lepus nigricollis (LC) & Leporidae $^{*}$ & Jungle hare \\
\hline Boselaphus tragocamelus (VU) & Bovidae* $^{*}$ & Blue bull \\
\hline Axix axix (VU) & Cervidae* $^{*}$ & Spotted deer \\
\hline Sus scrofa (LC) & Suidae* & Wild boar \\
\hline Elephas maximus (EN, I) & Elephantidae $^{* *}$ & Asian elephant \\
\hline Bandicota indica (LC) & Muridae* & Jungle rat \\
\hline
\end{tabular}

${ }^{*}$ Seen. ${ }^{* *}$ Reported from focus group discussions (FGD) and key informants interviews (KII).

EN: endangered, VU: vulnerable, NT: near threatened, LC: least concern (IUCN Red List Category); I, II: CITES categories (source: Jnawali et al. [72]).

TABLE 7: Reptiles directly observed in the Ghodaghodi Lake complex.

\begin{tabular}{lcc}
\hline Scientific name & Family & Common name \\
\hline $\begin{array}{l}\text { Crocodylus } \\
\text { palustris (VU, I ) }\end{array}$ & Crocodylidae & Marsh mugger \\
$\begin{array}{l}\text { Python molurus } \\
\text { (NT, I) }\end{array}$ & Pythonidae & Python
\end{tabular}

Kachuga tecta Geoemydidae Indian roofed turtle

(LC)

Geoemydidae

Kachuga Geoemydidae Red crowned roofed turtle

kachuga (CR)

Lissemys

punctata (LC)

Varanus

flavescens (LC, I)

Trionychidae

Flap shell turtle

V: vulnerable, CR: critically endangered, NT: near threatened, LC: least concern (IUCN Red List Category) (source: IUCN [73]); I: CITES category.

and pigeons on the shore, which ultimately becomes a source of pollution. A few past studies [20, 22, 77] also documented cultural and religious activities as a major source of pollution. Recreational activities in the form of picnicking are a common practice inside the complex. The movement of people and the loud music system played for such recreation negatively impact the faunal species including birds.

During the last two decades, land use of the complex has changed due to the encroachment of migrants from the hilly districts of far western region. Forest area has decreased at the expense of agricultural land while forest cover has been converted into open grazing land, displacing the habitat of important birds and wildlife. 
Water extraction for irrigation and water use for buffalo wallowing has severely affected the habitat. This study observed both Ghodaghodi and Nakharodi Lakes having a canal used for irrigation purposes, a practice that becomes even more intense during dry periods. Landowners and farmers downstream from the lake have a vested interest to secure water for irrigation. The lake complex does not have a permanent perennial source of water and this extraction system, especially in the dry season, greatly affects the aquatic life and migratory birds.

The southeastern part of Ghodaghodi Lake and eastern parts of Nakharodi Lake have been heavily affected by livestock grazing. As the occupation of most of the villagers used to be farming as well as rearing livestock, grazing the forests and open grasslands of the lake area is common. However, the trampling of soil and browsing of young palatable species from this traditional practice has damaged the regeneration capacity of native vegetation in the area.

Dichlorvos 76\% EC and Endosulfan 35\% EC were the major pesticides used, while urea and diammonium phosphate (DAP) were the major fertilizers used in crops near the lake vicinity. The seepage of such pesticides and fertilizers through agricultural runoff has caused eutrophication in the lake. As a result, excessive growth of aquatic macrophytes such as Ceratophyllum demersum, Nelumbo nucifera, Naja minor, Pistia stratiotes, and Hydrilla verticillata from the water surface was evident. Siwakoti and Karki [20] reported the occurrence of both the natural and human caused eutrophication at Ghodaghodi Lake complex with the invasion of Ipomea fistulosa and Salix spp. Eutrophication from agricultural runoff and invasion of water hyacinth were also reported by Shrestha [42] at Koshi Tappu wetland.

Siltation emerging from the degradation of upper watershed areas is another reason for habitat destruction. Rapid deforestation and encroachment in the watershed area within Betini forest, a major source of water, is causing reduced water supply to the lake. Overgrazing of the grassland at the watershed has also increased soil erosion and siltation. This finding is similar to that of [77]. In Nepal, nearly $69 \%$ of wetlands are threatened by sedimentation and siltation while $61 \%$ by agricultural runoff [7].

\section{Conclusion and Recommendation}

This study, a month long summer season survey, documents the existing biodiversity, the use pattern of floral diversity by the local people, and anthropogenic threats to the overall biodiversity of Ghodaghodi Lake complex. The Ghodaghodi Lake complex was found to be a very rich wetland diversity hotspot in the western low-land region of Nepal, though variations in the number of species than those of previous study by IUCN [7] and Kafle [22] were recorded. Within such a small territory, the existence of such a vast number of both the floral and faunal diversity is really an encouraging sign for conservation. The lake resources, especially aquatic and terrestrial plants, were traditionally been used for different purposes including medicinal, food, fodder, fruit, fuel wood, timber, and industrial. Among them, medicinal uses were a main priority for the local people because they have been traditionally practiced in the locality and are a good alternative to the health care system. However, the data revealed that most of the plant species were still untouched because of a lack of local knowledge on their potential value and utilization. This shows a scope in the exploration of ethnobotanical knowledge of the plant species in the Ghodaghodi Lake complex. If proper conservation and sustainable utilization is ensured, then the lake resources can have a good economic contribution to the lives of local people.

The paradox is however the threats in the area, mostly anthropogenic in nature, which could lead to an imbalance of the natural wetland ecosystem. If immediate conservation action is not put in place, then there is a likelihood that most of the threatened category animals will be in danger due to the anthropogenic threats identified by this study. The results show that Ghodaghodi Lake complex has an enormous economic and conservational potential and care should be taken to maintain its biodiversity value. The economic potential and multipurpose use of plant species, including medicinal values, could supplement the household income of the local people and be a good incentive for them for conservation. We recommend (1) more exploration of the indigenous lake resource uses including medicinal potential of available plant species, (2) prioritizing in situ biodiversity conservation, and (3) implementing awareness programs at local levels on the consequence of threats to lake biodiversity.

\section{Conflict of Interests}

The authors declare that there is no conflict of interests regarding the publication of this paper.

\section{References}

[1] W. I. Mitsch and I. G. Gosselink, Wetlands, Van Nostrand Reinhold, New York, NY, USA, 1986.

[2] MFSC, Nepal Biodiversity Strategy, Ministry of Forest and Soil Conservation, Kathmandu, Nepal, 2002.

[3] P. Dugan, Wetlands in Danger: A World Conservation Atlas, Oxford University Press, New York, NY, USA, 1993.

[4] A. R. Joshi and D. P. Joshi, "Endemic plants of Nepal Himalaya: conservation status and future direction," Mountain Environment and Development, vol. 1, no. 2, pp. 1-35, 1991.

[5] IUCN, A Review of the Status and Threats to Wetlands in Nepal, IUCN Nepal, Kathmandu, Nepal, 2004.

[6] BirdLife International, Lists of Globally Threatened and NearThreatened Species in Nepal, 2010.

[7] IUCN, The Ghodaghodi Tal Conservation Area: A Community Centred Management Plan, IUCN Nepal, Kathmandu, Nepal, 1998.

[8] U. R. Sharma, K. J. Malla, and R. K. Uprety, "Conservation and management efforts of medicinal and aromatic plants in Nepal," Banko Janakari, vol. 14, pp. 3-11, 2004.

[9] S. Bhattarai, R. P. Chaudhary, and R. S. L. Taylor, "Ethnomedicinal plants used by the people of Manang district, central Nepal," Journal of Ethnobiology and Ethnomedicine, vol. 2, article 41, 2006. 
[10] R. M. Kunwar and R. W. Bussmann, "Ethnobotany in the Nepal Himalaya," Journal of Ethnobiology and Ethnomedicine, vol. 4, article 24, 2008.

[11] R. Acharya and K. P. Acharya, "Ethnobotanical study of medicinal plants used by Tharu Community of Parroha VDC, Rupendehi District, Nepal," Scientific World, vol. 7, no. 7, pp. 8084, 2009.

[12] M. Karki and J. T. Williams, Priority Species of Medicinal Plants in South Asia, Medicinal and Aromatic Plants Program in Asia (MAPPA), IDRC/SARO, New Delhi, India, 1999.

[13] S. K. Ghimire, "Sustainable harvesting and management of medicinal plants in the Nepal Himalaya: current issues, knowledge gaps and research priorities," in Medicinal Plants in Nepal: an Anthology of Contemporary Research, P. K. Jha, S. B. Karmarachraya, M. K. Chhetri, C. B. Thapa, and B. B. Shrestha, Eds., pp. 25-44, Ecological Society of Nepal (ECOS), Kathmandu, Nepal, 2008.

[14] S. R. Baral and P. P. Kurmi, A Compendium of Medicinal Plants in Nepal, vol. 281, Mrs. Rachana Sharma, Maujubahal, Chabahil, Kathmandu, Nepal, 2006.

[15] D. Romport, M. Andreas, and B. Vlasakova, "Monitoring of biodiversity changes in the landscape scale," Journal of Landscape Ecology, vol. 1, no. 1, pp. 49-68, 2008.

[16] Millennium Ecosystem Assessment, Ecosystems and Human Well-Being: Wetlands and Water Synthesis, World Resources Institute, Washington, DC, USA, 2005.

[17] D. Sonal, R. Jagruti, and P. Geeta, "Avifaunal diversity and water quality analysis of an inland wetland," Journal of Wetland Ecology, vol. 4, pp. 1-32, 2010.

[18] K. D. Schuyt, "Economic consequences of wetland degradation for local populations in Africa," Ecological Economics, vol. 53, no. 2, pp. 177-190, 2005.

[19] D. Dudgeon, A. H. Arthington, M. O. Gessner et al., "Fresh water biodiversity: importance, threats, status and conservation challenges," Biological Reviews of the Cambridge Philosophical Society, vol. 81, no. 2, pp. 163-182, 2006.

[20] M. Siwakoti and J. B. Karki, "Conservation status of Ramsar Sites of Nepal Tarai: an overview," Botanica Orientalis, vol. 6, pp. 76-84, 2009.

[21] J. A. McNeely, Economics and Biological Diversity: Developing and Using Economic Incentives to Conserve Biological Resources, IUCN, Gland, Switzerland, 1988.

[22] G. Kafle, "Avifaunal survey and vegetation analysis focusing on threatened and near-threatened species on Ghodaghodi Lake of Nepal," A Report Submitted to Oriental Bird Club (OBC), Bedford, UK, 2005.

[23] Y. B. Bam, "Conservation and Sustainable Use of Ghodaghodi Lake System," Technical Report submitted to IUCN Nepal, 2002.

[24] J. P. Sah and J. T. Heinen, "Wetland resource use and conservation attitudes among indigenous and migrant peoples in Ghodaghodi Lake area, Nepal," Environmental Conservation, vol. 28, no. 4, pp. 345-356, 2001.

[25] CBS, National Census Report of 2001, Central Bureau of Statistics, Government of Nepal, 2001.

[26] CBS, National Census Report of 2011, Central Bureau of Statistics, Government of Nepal, 2011.

[27] J. A. Ludwig and J. F. Reynolds, Statistical Ecology: A Primer of Methods and Computing, Wiley Press, New York, NY, USA, 1988.
[28] H. Hara, A. O. Chater, and L. H. J. Williams, An Enumeration of Flowering Plants of Nepal, vol. III, British Meuseum (Nat. Hist.), London, UK, 1982.

[29] C. D. K. Cook, Aquatic and Wetland Plants of India, Oxford University Press, 1996.

[30] J. R. Press, K. K. Shrestha, and D. A. Sutton, Annotated Checklist of the Flowering Plants of Nepal, The Natural History Museum, London, UK, 2000.

[31] E. M. Bursche, A Hand Book of Water Plants, Oriental Enterprise, Dehradun, India, 1991.

[32] D. R. Dongol, "Economic uses of forest plant resources in Western Chitwan, Nepal," Banko Janakari, vol. 12, no. 2, pp. 5664, 2002.

[33] R. P. Choudhary, Biodiversity in Nepal: Status and Conservation, 1998.

[34] N. P. Manandhar, Medicinal Plants of Nepal Himalaya, Ratna Pustak Bhandar, Kathmandu, Nepal, 1980.

[35] T. K. Rajbhandary, M. S. Bista, and V. L. Gurung, Enumeration of the Vascular Plants of West Nepal, Ministry of Forests and Soil Conservation, Department of Plant Resources, Thapathali, Kathmandu, Nepal, 1994.

[36] J. Shrestha, Enumeration of Fishes of Nepal, Biodiversity Profile Project, Publication no. 10, Department of National Parks and Wildlife Conservation, Ministry of Forest and Soil Conservation, Government of Nepal, Kathmandu, Nepal, 1995.

[37] BCN and DNPWC, Birds of Nepal-An Official Checklist for Nepal, Bird Conservation Nepal and Department of National Park and Wildlife Conservation, 2006.

[38] B. P. Sarmah, D. Baruah, and B. Bakalial, "Wetland medicinal plants in floodplains of Subansiri and Ranga River of Lakhimpur District, Assam, India," Asian Journal of Plant Science and Research, vol. 3, no. 3, pp. 54-60, 2013.

[39] B. Niroula and K. L. B. Singh, "Aquatic plant resources of Betana Wetland, Morang, Nepal," Our Nature, vol. 9, pp. 146-155, 2011.

[40] A. R. Joshi and K. Joshi, "Ethnomedicinal plants used against skin diseases in some villages of Kali Gandaki, Bagmati, and Tadi Likhu watersheds of Nepal," Ethnobotanical Leaflets, vol. 11, pp. 235-246, 2007.

[41] M. K. Misra, A. Panda, and S. Deenabandhu, "Survey of useful wetland plants of South Odisha, India," Indian Journal of Traditional Knowledge, vol. 11, no. 4, pp. 658-666, 2012.

[42] P. Shrestha, "Diversity of aquatic macrophytes in the Koshi Tappu Wildlife Reserves and surrounding areas, Eastern Nepal," in Environmental and Biodiversity: in the Context of South Asia. 2003-2011, P. K. Jha, G. P. S. Ghimire, S. B. Karmacharya, S. R. Baral, and P. Lacoul, Eds., 1996.

[43] B. Niroula and K. L. B. Singh, "Contribution to aquatic macrophytes of Biratnagar and adjoining areas, Eastern Nepal," Ecoprint, vol. 17, pp. 23-34, 2010.

[44] A. R. Mohammad, O. F. Mohammad, and A. H. Mohammad, "Environment friendly antibacterial activity of water chesnut fruits," Journal of Biodiversity and Environmental Sciences, vol. 1, pp. 26-34, 2011.

[45] M. S. Hossan, A. Hanif, B. Agarwala et al., "Traditional use of medicinal plants in Bangladesh to treat urinary tract infections and sexually transmitted diseases," Ethnobotany Research and Applications, vol. 8, pp. 61-74, 2010.

[46] R. B. Mahato, "Notes on some plants of ethnomedicinal importance from Palpa district," Tribhuvan University Journal, vol. 21, no. 1, pp. 71-76, 1998. 
[47] N. P. Balami, "Ethnomedicinal uses of plants among the Newar community of Pharping Village of Kathmandu district, Nepal," Journal of Tribhuvan University, vol. 24, no. 1, p. 10, 2004.

[48] A. G. Singh, M. P. Panthi, and D. D. Tewari, "Ethno medicinal plants used by the Tharu and Magar communities of Rupendehi District, Western Nepal," Current Botany, vol. 2, no. 2, pp. 30-33, 2011.

[49] R. M. Kunwar, Y. Uprety, C. Burlakoti, C. L. Chowdhary, and R. W. Bussmann, "Indigenous use and ethnopharmacology of medicinal plants in far-west Nepal," Ethnobotany Research and Applications, vol. 7, pp. 5-28, 2009.

[50] M. Ayyanar and S. Ignacimuthu, "Ethnobotanical survey of medicinal plants commonly used by Kani tribals in Tirunelveli hills of Western Ghats, India," Journal of Ethnopharmacology, vol. 134, no. 3, pp. 851-864, 2011.

[51] N. Dhami, "Ethnomedicinal uses of plants is Western Terai of Nepal: a case study of Dekhatbhuli VDC of Kanchanpur district," in Medicinal Plants in Nepal: An Anthology of Contemporary Research, P. K. Jha, S. B. Karmacharya, M. K. Chhetry, C. B. Thapa, and B. B. Shrestha, Eds., pp. 165-177, Ecological Society of Nepal (ECOS), Kathmandu, Nepal, 2008.

[52] M. Z. Chopda and R. T. Mahajan, "Wound healing plants of Jalgaon District of Maharashtra State, India," Ethnobotanical Leaflets, vol. 13, pp. 1-32, 2009.

[53] S. S. Ahmad, "Medicinal wild plants from Lahore-Islamabad motorway (M-2)," Pakistan Journal of Botany, vol. 39, no. 2, pp. 355-375, 2007.

[54] Y. Uprety, R. C. Poudel, H. Asselin, and E. Boon, "Plant biodiversity and ethnobotany inside the projected impact area of the Upper Seti Hydropower Project, Western Nepal," Environment, Development and Sustainability, vol. 13, no. 3, pp. 463-492, 2011.

[55] K. Hussain, A. Shahazad, and S. Z. Hunssnain, "An ethnobotanical survey of important wild medicinal plants of Hattar District Haripur, Pakistan," Ethnobotanical Leaflets, vol. 12, pp. 29-35, 2008.

[56] N. P. Manandhar, "Native phytotherapy among the Raute tribes of Dadeldhura district, Nepal," Journal of Ethnopharmacology, vol. 60, no. 3, pp. 199-206, 1998.

[57] Y. Uprety, E. K. Boon, R. C. Poudel et al., "Non-timber forest products in Bardiya district of Nepal: indigenous use, trade and conservation," Journal of Human Ecology, vol. 30, no. 3, pp. 143$158,2010$.

[58] R. B. Mahato and R. P. Chaudhary, "Ethnomedicinal study and antibacterial activities of selected plants of Palpa district, Nepal," Scientific World, vol. 2, pp. 38-45, 2003.

[59] A. G. Singh, A. Kumar, and D. D. Tewari, "An ethnobotanical survey of medicinal plants used in Terai forest of western Nepal," Journal of Ethnobiology and Ethnomedicine, vol. 8, p. 19, 2012.

[60] P. P. Sapkota, "Ethnoecological observation of Magar of Bakuni, Baglung, Western Nepal, Dhaulagiri," Journal of Sociology and Anthropology, vol. 2, pp. 227-252, 2008.

[61] D. M. A. Jayaweera, Medicinal Plants (Indigenous and Exotic) Used in Ceylon, Part 3, The National Science Foundation, Colombo, Sri Lanka, 2006.

[62] M. M. Hasan, E. A. Annay, M. Sintaha et al., "A survey of medicinal plant usage by folk medicinal practitioners in seven villages of Ishwardi Upazilla, Pabna District, Bangladesh," American-Eurasian Journal of Sustainable Agriculture, vol. 4, no. 3, pp. 326-333, 2010.
[63] K. Joshi, R. Joshi, and A. R. Joshi, "Indigenous knowledge and uses of medicinal plants in Macchegaun, Nepal," Indian Journal of Traditional Knowledge, vol. 10, no. 2, pp. 281-286, 2011.

[64] S. Bhattarai, B. Pant, and C. P. Upadhyaya, "Dependency of Tharu communities on wild plants: a case study of Shankarpur, Kanchanpur district," Banko Janakari, vol. 21, no. 1, pp. 35-40, 2011.

[65] T. Krishnamurty, Minor Forest Product of India, Oxford \& IBH Publishing, New Delhi, India, 1993.

[66] M. Rahmatullah, M. N. K. Azam, M. M. Rahman et al., "A survey of medicinal plants used by garo and non-garo Traditional Medicinal Practitioners in Two Villages of Tangail District, Bangladesh," American-Eurasian Journal of Sustainable Agriculture, vol. 5, no. 3, pp. 350-357, 2011.

[67] P. K. Rai and H. Lalramnghinglova, "Ethnomedicinal plant resources of Mizoram, India: implication of traditional knowledge in health care system," Ethnobotanical Leaflets, vol. 14, pp. 274-305, 2010.

[68] B. P. Gaire and L. Subedi, "Medicinal plant diversity and their pharmacological aspects of Nepal Himalayas," Pharmacognosy Journal, vol. 3, no. 25, pp. 6-17, 2011.

[69] S. A. Mukul, M. B. Uddin, and M. R. Tito, "Medicinal plant diversity and local healthcare among the people living in and around a conservation area of Northern Bangladesh," International Journal of Forest Usufructs Management, vol. 8, no. 2, pp. 50-63, 2007.

[70] A. G. Singh and J. P. Hamal, "Traditional phytotherapy of some medicinal plants used by Tharu and Magar communities of Western Nepal, against dermatological disorders," Scientific World, vol. 11, no. 11, pp. 81-89, 2013.

[71] H. S. Baral, "Updated status of Nepal's wetland birds," Banko Janakari, (Wetland Special Issue), pp. 30-35, 2009.

[72] S. R. Jnawali, H. S. Baral, S. Lee et al., The Status of Nepal Mammals: The National Red List Series, The National Red List Series, Department of National Parks and Wildlife Conservation, Kathmandu, Nepal, 2011.

[73] IUCN, IUCN Red List of Threatened Species. Version 2013.2, 2013, http://www.iucnredlist.org/.

[74] R. J. Naiman, J. J. Magnuson, D. M. McKnight, and J. A. Stanford, The Freshwater Imperative: A Research Agenda, Island Press, Washington, DC, USA, 1995.

[75] D. J. Rapport and W. G. Whitford, "How ecosystems respond to stress: common properties of arid and aquatic systems," BioScience, vol. 49, no. 3, pp. 193-203, 1999.

[76] B. B. Bhandari, "Wise use of wetlands in Nepal," Banko Janakari, (Wetland Special Issue): pp. 10-17, 2009.

[77] P. K. Neupane, M. Khadka, R. Adhikari, and D. R. Bhuju, "Lake water quality and surrounding vegetation in Dry Churiya Hills, Far-Western Nepal," Nepal Journal of Science and Technology, vol. 11, pp. 181-188, 2010. 

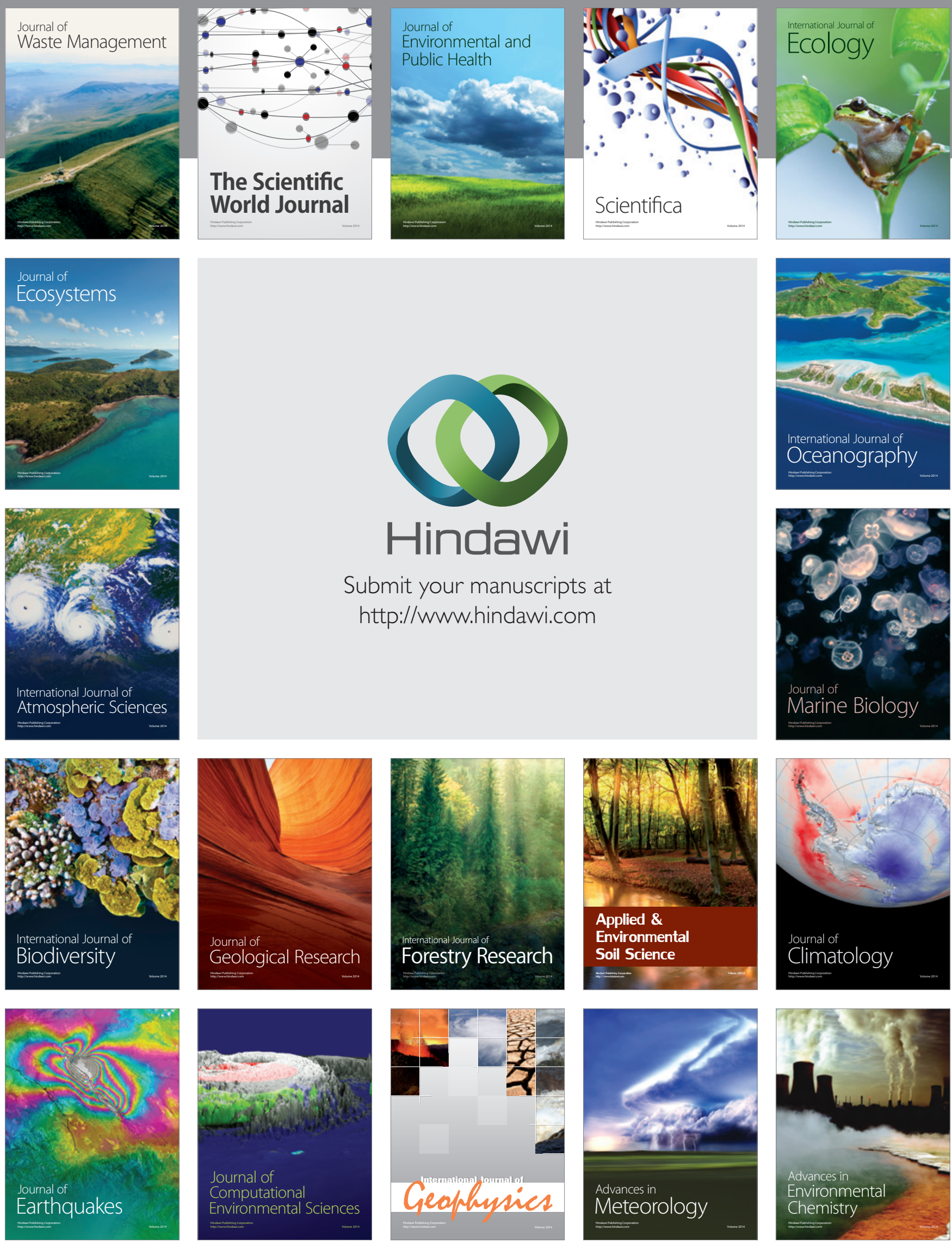